
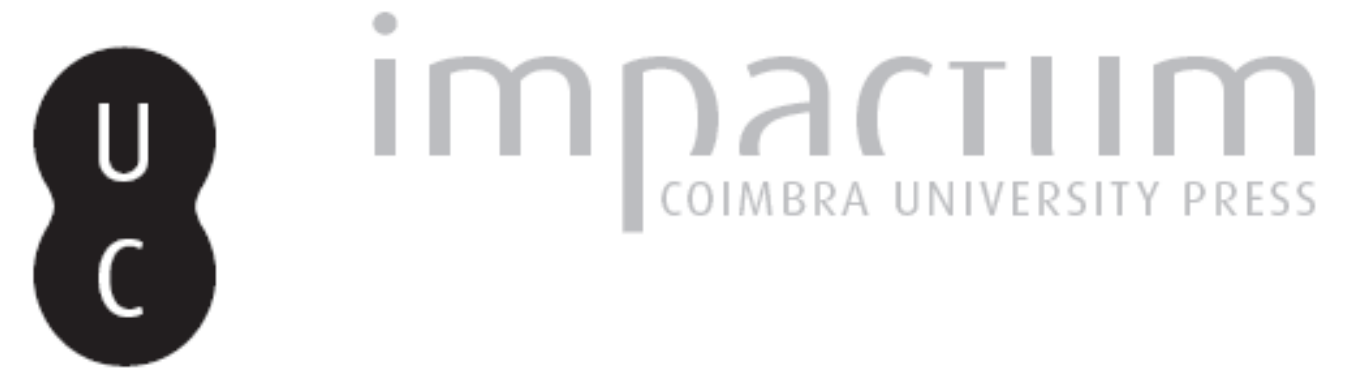

\title{
Património e rendas do Cabido da Sé de Coimbra no séc. XVII
}

Autor(es): $\quad$ Silva, Hugo Daniel Ribeiro da

Publicado por: Imprensa da Universidade de Coimbra

URL persistente:

URI:http://hdl.handle.net/10316.2/45007

DOI:

DOI:https://doi.org/10.14195/0870-4147_38_12

Accessed : $\quad$ 26-Apr-2023 13:58:38

A navegação consulta e descarregamento dos títulos inseridos nas Bibliotecas Digitais UC Digitalis, UC Pombalina e UC Impactum, pressupõem a aceitação plena e sem reservas dos Termos e Condições de Uso destas Bibliotecas Digitais, disponíveis em https://digitalis.uc.pt/pt-pt/termos.

Conforme exposto nos referidos Termos e Condições de Uso, o descarregamento de títulos de acesso restrito requer uma licença válida de autorização devendo o utilizador aceder ao(s) documento(s) a partir de um endereço de IP da instituição detentora da supramencionada licença.

Ao utilizador é apenas permitido o descarregamento para uso pessoal, pelo que o emprego do(s) título(s) descarregado(s) para outro fim, designadamente comercial, carece de autorização do respetivo autor ou editor da obra.

Na medida em que todas as obras da UC Digitalis se encontram protegidas pelo Código do Direito de Autor e Direitos Conexos e demais legislação aplicável, toda a cópia, parcial ou total, deste documento, nos casos em que é legalmente admitida, deverá conter ou fazer-se acompanhar por este aviso.

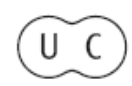



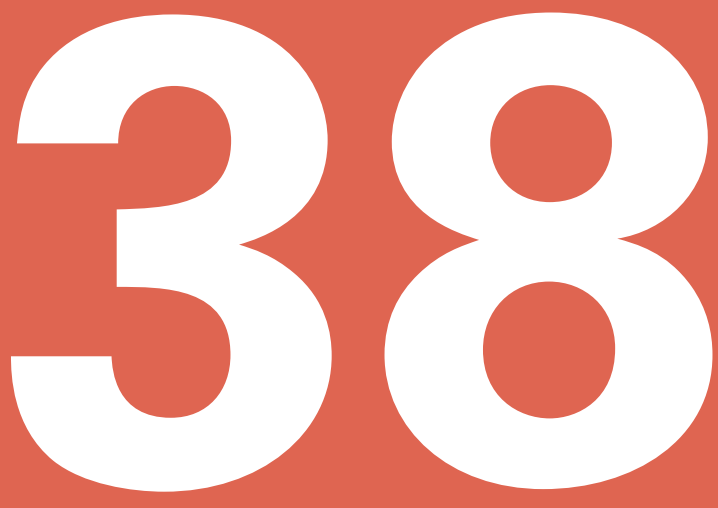

\section{Revista Portuguesa de História}

Faculdade de Letras da Universidade de Coimbra Instituto de História Económica e Social

Coimbra 08 
Revista Portuguesa de História

t. XXXVIII (2006)

pp. 347-376

\section{Património e rendas do Cabido da Sé de Coimbra no séc. XVII*}

Hugo Daniel Ribeiro da Silva

Doutorando Instituto Universitário Europeu, Florença Bolseiro da Direcção-Geral dos Assuntos Comunitários e da FCT

\section{Introdução}

Uma das funções inerentes aos cabidos catedralícios era a de administração económica da instituição, organizando-a minuciosamente de forma a cumprir um objectivo que interessava a todos os capitulares: proporcionar-lhes boas rendas. No entanto, é-nos muito difícil conhecer, com exactidão, qual o valor das rendas eclesiásticas de que desfrutavam os membros do Cabido. Tal deve-se a uma administração económica complexa de um património disperso e de diferentes naturezas ${ }^{1}$, que se encontra

* Agradeço à Dra. Helena Osswald e à Prof. Doutora Inês Amorim as sugestões feitas ao presente texto, bem como ao Dr. Miguel Nogueira por toda a discussão de ideias provocada com a construção dos mapas que aqui apresento.

1 A mesma dificuldade é descrita por IRIGOYEN LÓPEZ, 2001: 142-143; CANÓVAS BOTÍA, 1994: 564-565. LATORRE CIRIA, que realizou um estudo económico da catedral de Huesca, diz-nos que la organización administrativa de la Catedral descansa sobre varias administraciones que se ocupan de gestionar las rentas según la finalidad especifica que han de cubrir. Sin embargo, los entrelazamentos entre las distintas unidades de gestión son frecuentes; este hecho unido a la técnica contable utilizada, dificulta enormemente el estudio de las rentas (LATORRE CIRIA, 1992: 286, 313). Na mesma obra o autor desenvolve estas questões (LATORRE CIRIA, 1992:17-34). 
ainda por estudar para a totalidade dos cabidos portugueses existentes na época moderna ${ }^{2}$.

Com o presente trabalho será nosso objectivo principal identificar qual a proveniência das rendas que o Cabido de Coimbra auferia, observando-se ainda de que forma eram distribuídas pelos seus membros, excluindo da análise a forma como o Cabido administrava o seu património e a evolução do valor das rendas por ele proporcionadas ao longo de determinado período do tempo, embora tal constitua tarefa fundamental a aguardar o interesse dos historiadores ${ }^{3}$.

\section{Fontes}

A documentação histórica do Cabido da Sé de Coimbra encontra-se hoje repartida entre a Torre do Tombo, principalmente a da Idade Média, e o Arquivo da Universidade de Coimbra (AUC), sobretudo a da época Moderna. Como, no AUC, não existe um inventário geral do fundo do Cabido, apenas uma listagem, consultámos diversas tipologias documentais que pareciam estar relacionadas com a organização económica da instituição. Deixando para depois uma breve descrição do conteúdo das fontes, importa desde já enunciá-las. Podemos, por um lado, identificar aquelas que eram produzidas no âmbito da administração das rendas (no seu arrendamento, por exemplo) - livros de foros, de capões, de receita das pensões em azeite, das rendas da massa/ordinárias/terças, de pensões e censorias, do celeiro, de receitas e despesas e das festas dos beneficiados; e, por outro, aquelas que diziam respeito à distribuição das rendas pelos capitulares - livros de mesadas, de procissões e pitanças e de terradegos; embora, por vezes, alguns destes livros se possam inserir em ambas as tipologias, já que cumpriam o duplo objectivo de recolha/distribuição.

\section{Propriedades e Rendas}

Ao falarmos de património eclesiástico, ou, neste caso, de património capitular, não nos podemos limitar às propriedades fundiárias. Trata-se de dois conceitos que importa desde já distinguir. Na verdade, em sentido estrito

2 OLIVEIRA, 1999: 199-232.

3 Por vezes, alguns autores apresentam valores globais das rendas eclesiásticas desta ou daquela diocese, para determinado momento histórico, sugeridos por fontes como as visitas ad limina. Contudo, tais fontes não permitem distinguir entre rendimentos fundiários ou imobiliários ou entre as diversas entidades proprietárias; além de, obviamente, não permitirem a análise da evolução das rendas ao longo do tempo e, muito menos, perceber a forma como elas eram geridas. Visto que existem fontes que permitem ir mais além, urge dar-lhes atenção... 
o Direito Canónico falava pouco de propriedade e muito mais de património eclesiástico: complexo de bens temporais destinados ao uso pela Igreja ${ }^{4}$.

Em termos gerais, o património do Cabido era composto, desde logo, por um conjunto de bens utilizados no âmbito do culto: alguns dos templos da diocese e alfaias litúrgicas pertencentes aos mesmos, entre as quais se incluem as da própria Sé. Além destes, estritamente religiosos, havia todo um conjunto de propriedades - casas, terras e unidades de transformação - do qual era senhorio, e que lhe proporcionavam rendas em dinheiro e em géneros.

Enquanto instituição eclesiástica que era, o Cabido contava ainda com todo um vasto conjunto de rendas provenientes das funções que desempenhava e do lugar que ocupava na sociedade de Antigo Regime, nomeadamente todas aquelas provenientes de, por exemplo, instituição de capelas e, de forma mais alargada, todo um conjunto de "impostos religiosos", de que se destaca o dízimo.

Para o estudo das propriedades do Cabido recorremos ao designado "Index das casas e propriedades do Cabido", que datará de 1634, embora não tenhamos conseguido confirmar esta data ${ }^{5}$. Tal problema com a datação exacta do livro é apenas um dos elementos a dificultar a crítica desta fonte. De facto, não nos foi possível, conhecer, até ao momento, em que contexto foi produzido, isto é, o que motivou o Cabido a elaborá-lo. Quer aquela designação, que se encontra na lombada do livro, quer a que surge numa das primeiras folhas - Padrão das casas da See de Coimbra e suas propriedades-, parecem ter sido atribuídas em data posterior, provavelmente aquando de nova encadernação do mesmo.

Mas, afinal, qual o conteúdo deste livro? Na verdade, ele assemelha-se aos livros de foros $^{6}$, existentes entre a documentação do Cabido. Na gestão dos foros o Cabido produziu vários tipos de livros. Para os pagamentos em dinheiro tinha os livros com o mesmo nome; para os que eram feitos em géneros tinha os das "aves", do "azeite" e os do "celeiro", aos quais faremos menção mais à frente. Contudo, enquanto cada um destes livros só regista as propriedades que pagam a totalidade ou parte do foro em dinheiro ou num daqueles géneros, o Index apresenta-nos todas elas. Além disso, por vezes surgem informações qualitativas no Index que não surgem nos livros de foros, e enquanto a estes pode ser atribuída uma única data, naquele, ainda que não se saiba com exactidão quando foi elaborado, registaram-se informações em datas posteriores, embora, por vezes,

4 Vd., por exemplo, STUMPO, 1986: 266-267. Este autor alerta para a confusão que por vezes surge entre os dois conceitos. Diz ainda que importa também distinguir entre bens eclesiásticos e bens de privados com funções eclesiásticas.

5 AUC - Cabido, Index das casas e propriedades do Cabido - III/D,1,3,4,14 [ano 1634].

6 AUC- Cabido, Livros de Foros- III/D,1,3,5,248 (1621); III/D,1,3,1,175 (1660-1663); III/D,1,4,1,26 (1708-1722). 
sem as mencionar. Em suma, tudo parece indicar-nos que este livro surgiu da necessidade do Cabido possuir um inventário de todas as suas propriedades, de forma a uma melhor gestão de um património que, como veremos, era numeroso e estava disperso pela diocese e outros pontos do país.

Neste livro podem, então, ser identificadas as propriedades - localização, composição, "inquilinos"... - e quanto é que pagavam, em dinheiro e/ou géneros. Quanto à localização, geralmente é-nos indicado o lugar (no caso da cidade de Coimbra é mesmo indicada a rua), mas nem sempre a freguesia, o que dificultou a localização exacta das mesmas. Quanto à composição, ou tipo de propriedade, fomos obrigados a fazer algumas opções quanto ao tratamento da informação. Na verdade, existe uma grande diversidade de tipos de propriedades, resultante de uma multiplicidade de combinações possíveis. Em primeiro lugar estabelecemos três grandes categorias de propriedades: urbanas, rurais e unidades de transformação. Em cada uma delas criámos várias classes, tentando aí agrupar, dentro de uma mesma grande categoria, as diversas tipologias documentadas. Contudo, visto que, por vezes, sob um mesmo "contrato" era possível encontrar mais do que uma daquelas três grandes categorias, optou-se por, nestes casos, subdividir a informação, e remeter cada uma das propriedades para a tipologia respectiva (por exemplo, uma quinta para a segunda e os moinhos para a terceira). Ou seja, o número de propriedades representadas nos mapas temáticos (vd. mapa 2 e mapas em anexo) é superior ao representado no mapa dos prazos (mapa 1). Assim, embora perdendo-se a unidade da informação, tornou-se mais fácil a sua representação cartográfica e análise. Além do mais, a representação quantitativa da informação estava, à partida, condicionada pela fonte, já que esta não nos indica as dimensões das propriedades, e só muito raramente é explícita quanto ao número de unidades emprazadas sob um mesmo contrato. Em suma, os números que aqui apresentamos são apenas aproximados, o que, pensamos, não impede uma análise da informação e não impossibilita o cumprimento dos objectivos a que aqui nos propomos.

O Cabido de Coimbra possuía propriedades um pouco por toda a diocese. Contudo, como se observa no mapa 1, existia uma maior concentração nas freguesias de Coimbra e concelhos vizinhos. Na verdade, a cidade-sede da diocese concentrava mais de metade das propriedades do Cabido (430), seguida, com um número bastante inferior, por Condeixa-a-Nova (98). Nos outros concelhos nunca ia além das 20 propriedades. Refira-se ainda a quase ausência de propriedades no norte da diocese, no território que viria a dar origem, no século XVIII, à diocese de Aveiro, bem como em quase todo o espaço costeiro, com excepção das freguesias de Tavarede e Figueira, no actual concelho da 
Figueira da Foz. Mas o Cabido possuía ainda propriedades fora dos limites da diocese, quer a Sul - Leiria, Tomar, Santarém e Sintra -, quer a Norte - Braga, Guimarães, Cabeceiras de Basto e Paredes. É de acreditar que este património se tenha constituído, maioritariamente, ao longo da época medieval, mas esta é uma temática ainda por estudar para a diocese de Coimbra, ao contrário do que já conhecemos, por exemplo, para a arquidiocese de Braga. Por outro lado, não é de excluir que, ao longo dos séculos XVII e XVIII, este património tenha aumentado, fruto de, por exemplo, doações ou instituição de capelas, embora coloquemos a hipótese de tal não ter acontecido em número significativo.

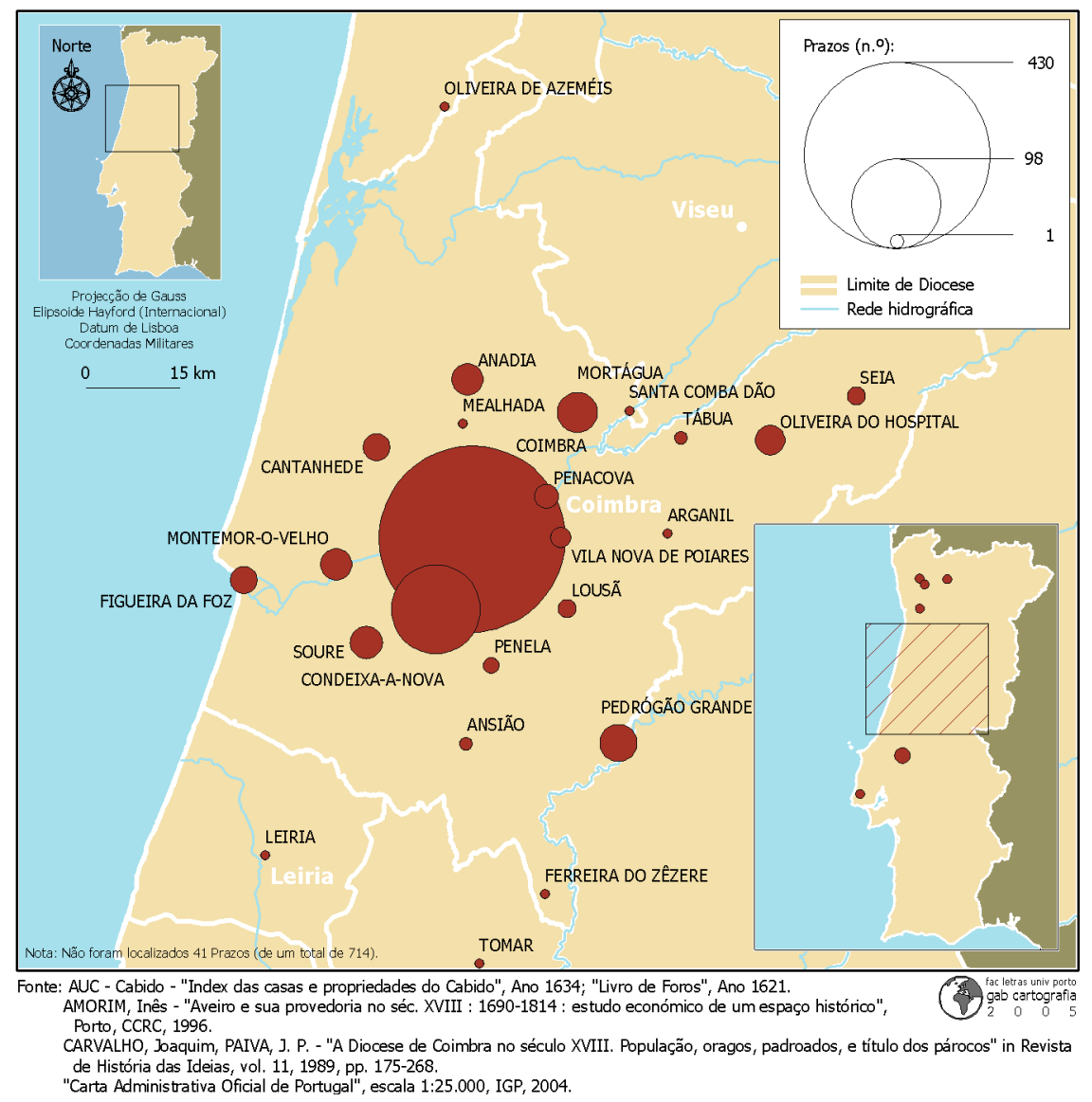

Mapa 1 - Os Prazos do Cabido da Sé de Coimbra no séc. XVII 
Uma maior aproximação a estas propriedades revela um predomínio de unidades de exploração agrária de diversos tipos (quintas, casais, hortas, vinhas, olivais...). Dada a diversidade, a que já nos referimos, de tipologias, designações e possíveis combinações de propriedades em simultâneo, foi necessário realizar algumas opções de forma a melhor poder sistematizar a informação. Foram considerados cinco grandes grupos - quintas/terras/casais; olivais; vinhas e olivais; almoinhas/hortas/quintal e vinhas -, nos quais se procuraram integrar todas as propriedades. A distribuição das unidades agrícolas pelo território da diocese coincide, de uma maneira geral, com a que observámos no mapa 1 , desde logo porque as propriedades rurais constituem cerca de $2 / 3$ do total de propriedades do Cabido. Entre as tipologias consideradas, predomina o grande conjunto composto por terras de cultivo de dimensões desconhecidas (291 em 485) - quintas, casais, "terras"...-, mas que, mesmo assim, pela sua designação, se podem distinguir de outras de menor dimensão - almoinhas, hortas, quintais... -, onde se produziria um pouco de tudo (um total de $21 \mathrm{em}$ 485). Em segundo lugar, com uma expressão inferior, mas significativa (146 em 485), surgem os olivais, maioritariamente situados em Coimbra, onde, aliás, são a tipologia predominante, confirmando o que já era conhecido sobre a paisagem que então caracterizava os arredores desta cidade, nomeadamente no que é hoje a freguesia de Santo António dos Olivais 7 . Com expressão reduzida surgem as vinhas, predominando apenas em 22 unidades de exploração, além daquelas em que surgem juntamente com olivais. Por último, refira-se que a fonte fornece-nos algumas (poucas) informações sobre mudanças na ocupação do solo, embora não as tenhamos aqui considerado, já que tal não interessava aos objectivos a que nos propusemos.

As propriedades urbanas eram constituídas sobretudo por casas, cinco delas com um quintal, localizadas na sua maioria na cidade de Coimbra (154 de um total de 192). Entre estas, algumas estavam exclusivamente reservadas a capitulares do próprio Cabido. Contudo, por conhecer ficam as dimensões e tipologias (térreas ou de sobrado) destas habitações, bem como o seu número real. Na verdade, o número total de casas será superior ao que aqui indicamos, já que, por vezes, é indicado que o pagamento se referia a mais do que uma casa, ou tal nos é sugerido pela fonte, embora de forma pouco clara e objectiva. Todavia, ainda que não saibamos o número exacto das casas, sabemos quanto, em conjunto, pagavam, o que, no fundo, é o que aqui mais nos interessa, já que as estamos a observar como fonte de rendimento do Cabido.

\footnotetext{
7 Oliveira, 1976-1977: vol. 47, pp. 320-327; SOARES, 1995: 193 e ss.
} 
As unidades de transformação - moinhos, lagares e fornos - concentravam-se quase exclusivamente em Coimbra (23 em 57) e Condeixa-a-Nova (17 em 57), estando as restantes distribuídas por Anadia, Montemor-o-Velho, Figueira-da-Foz, Soure e Pedrógão Grande. Se em Coimbra cerca de metade destas unidades eram lagares, já em Condeixa predominavam os moinhos. A quantidade de olivais existentes nos aros da cidade explica esta prevalência dos lagares em Coimbra, já que eles tanto poderiam ser de vinho como de azeite, embora a fonte nem sempre o especifique.

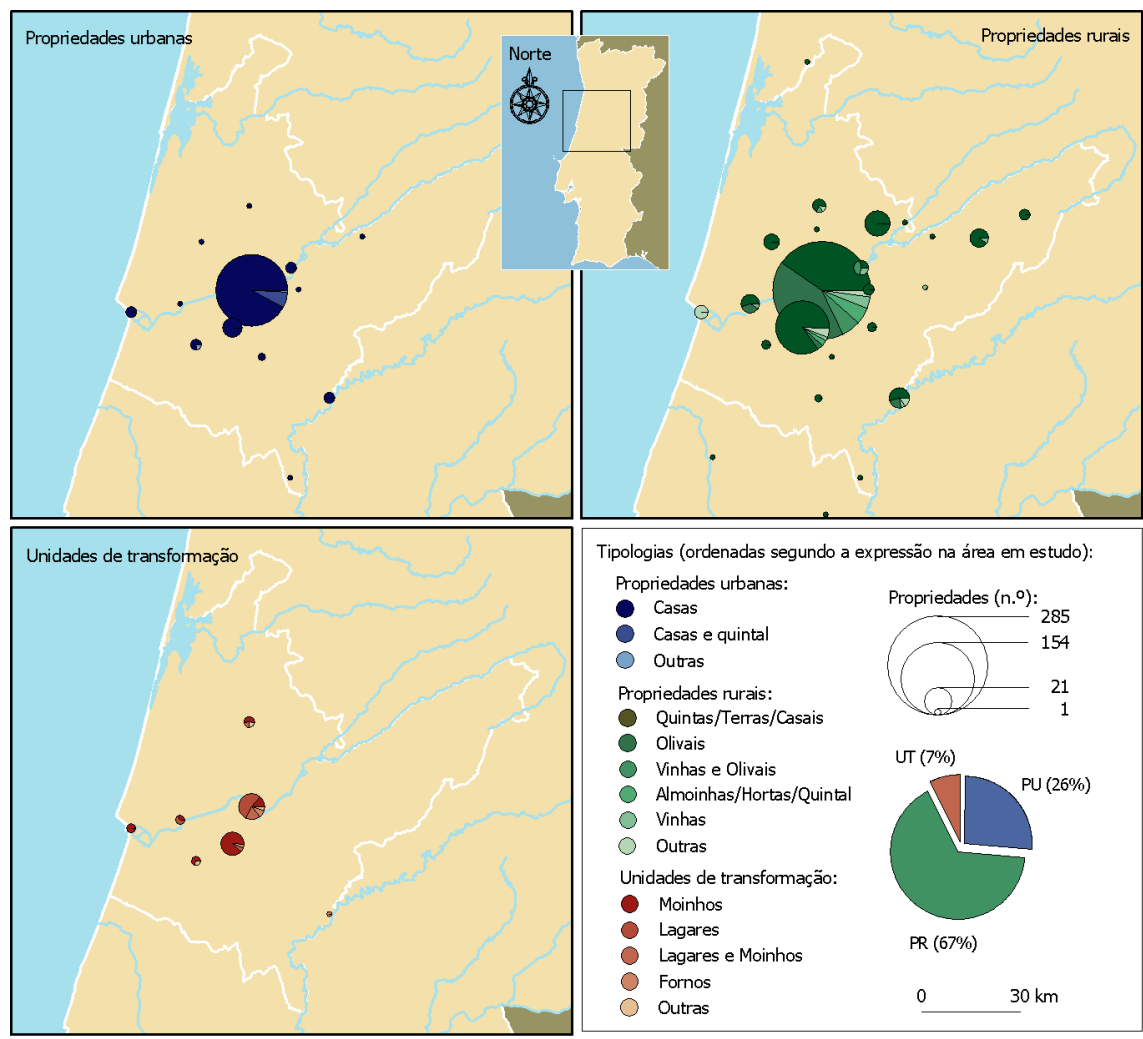

Fonte: AUC - Cabido - "Index das casas e propriedades do Cabido", Ano 1634; "Livro de Foros", Ano 1621.

AMORIM, Inês - "Aveiro e sua provedoria no séc. XVIII : 1690-1814 : estudo económico de um espaço histórico"

Porto, CCRC, 1996.

CARVALHO, Joaquim, PAIVA, J. P. - "A Diocese de Coimbra no século XVIII. População, oragos, padroados, e título dos párocos" in Revista de História das Ideias, vol. 11, 1989, pp. 175-268.

"Carta Administrativa Oficial de Portugal", escala 1:25.000, IGP, 2004.

Mapa 2 - Tipologias das propriedades do Cabido da Sé de Coimbra no século XVII ${ }^{1}$

1 Vd. também os mapas em anexo. 
Depois de apresentadas as propriedades do Cabido, importa agora saber que rendas proporcionavam. Os pagamentos realizados pelos inquilinos eram pagos em dinheiro, sobretudo quando se tratava de casas, em géneros ou ambos. Um dos aspectos a assinalar é que os valores pagos parecem não ter sofrido grandes alterações ao longo do século XVII, isto é, o valor do foro era relativamente fixo, o que se percebe já que na maior parte dos casos se tratava de pagamentos em géneros o que, tendo em conta a eventual oscilação dos preços, acabaria por beneficiar o Cabido, em particular em alturas de carestia. Por vezes, ainda que de forma esporádica, surge o equivalente em dinheiro a pagar em alternativa ao género. Trata-se, porém, de uma constatação algo empírica, ao compararmos o Index a alguns livros de foros, carecendo, portanto, de confirmação através de estudos mais exaustivos.

Em dinheiro o Cabido recebia cerca de 300 mil réis/ano, valor que não se pode considerar significativo, pelo contrário, já que, como veremos adiante, corresponde, aproximadamente, ao valor auferido anualmente por um único cónego no século XVII. Quanto aos géneros pagos, eles podiam ser em "aves", azeite e/ou cereal, sendo muito frequentes as combinações de mais do que um género e, dentro de cada um, de vários tipos. De azeite o Cabido recebia cerca de 1800 alqueires. Entre as aves predominava o pagamento em ovos e capões e, entre os cereais, o trigo, seguido pelo milho, embora, quando o pagamento incluía mais do que um tipo de cereal, nem sempre se distingam as quantidades correspondentes a cada um, sendo de supor que seriam equitativas. Além das quantidades apresentadas no quadro 1, seria importante, para melhor comparar o peso destes géneros no conjunto das rendas do Cabido, conhecer, por exemplo, qual o seu valor em dinheiro. Contudo, não nos foi possível conhecer o preço de todos estes géneros para determinado momento do século XVII .

Quadro 1 - Propriedades: pagamentos anuais ao Cabido (valores aproximados)

\begin{tabular}{|c|c|}
\hline Género & Quantidade $\left(\mathbf{n}^{\mathbf{0}}\right)$ \\
\hline capões & 1143 \\
\hline entrecosto & 6 \\
\hline frangões & 46 \\
\hline frangos & 6 \\
\hline galinhas & 167 \\
\hline ovos & 2549 \\
\hline pato & 0,5 \\
\hline
\end{tabular}

Dinheiro 293815 réis

\begin{tabular}{|c|c|}
\hline Género & Quantidade (alqueires) \\
\hline trigo & 994 \\
\hline milho & 539 \\
\hline trigo e milho & 274 \\
\hline trigo e cevada & 177 \\
\hline trigo de fogaça & 61 \\
\hline cevada & 43 \\
\hline pão meado & 37 \\
\hline centeio & 21 \\
\hline azeite & 1803 \\
\hline
\end{tabular}

Fonte: AUC - Cabido, Index das casas e propriedades do Cabido - III/D,1,3,4,14 [ano 1634].

8 Os dados obtidos são apresentados em anexo, servindo de instrumento de trabalho para quem, no futuro, pretenda desenvolver esta questão. 
Mas a parte mais significativa dos rendimentos do Cabido resultaria do pagamento dos dízimos e outras pensões eclesiásticas. Para o estudo deste rendimento contámos com uma tipologia documental que nem sempre teve a mesma designação: rendas, rendas da massa, rendas da mesa capitular, pautas das rendas, ordinárias, terças... Contudo, o conteúdo e a forma como o mesmo nos é apresentado são idênticos. Mas entre estes surge um, do ano de 1616 (mas com informações que recuam até 1598 e vão até 1654), com informações qualitativas que o distingue dos restantes, tendo sido, por isso, o livro que nos serviu de base para a análise desta renda. Na verdade, esta multiplicidade de designações pode até ser considerada um indicador de certa "desorganização" que existia no controlo destas rendas, levando em 1616 um dos cónegos a ordenar a elaboração deste livro, como nos é dito na primeira folha do mesmo:

Estas pautas das rendas da massa da seé de Coimbra se ajuntarão aqui por ordem do senhor Antonio de Oliveira e não vão apuradas como convem porque se não pode fazer bem feito sem se ir particularmente por cada uma das rendas, e perguntar o que ha nellas, e assi não serve este rascunho mais que para os curiozos e zellozos da casa tomarem daqui motivo para as aperfeiçoarem como comvem porque faule est inventis addere; e quando se fizer o primeiro arrendamento se pode alcansar dos rendeiros muitas cousas que aqui faltão; e pera isso lhe deixamos huma folha atras em cada renda pera alli se por o que for necessario pera boa declaração. E sendo tudo apurada com diligencia como comfiamos se farà, então se tratara de outro livro mais coriozo e não andarão voças merces todos os annos à cassa como costumavão fazer sobre pautas, e bastara recorrer a este livro onde se acharão. E onde se achar que faltão algumas rendas, entendasse que não forão aquelle anno arrendadas, e que os prebendeiros recolherão ou as derão a seus parentes e amigos et hoc sob censura sapientiorum, a trinta de Março de 1616. Valete (assinatura)". ${ }^{9}$

Além do registo do valor pelo qual a renda era arrendada de quatro em quatro anos, o livro indica-nos as igrejas e capelas cujas rendas eram arrendadas em conjunto com uma outra igreja principal, enquanto noutros livros apenas nos é indicada esta. Tal informação permitiu-nos, nos casos em que o valor da renda dizia respeito a mais do que uma igreja, distribuí-lo por todas elas, evitando assim que surgisse concentrado em apenas uma, o que conduziria e interpretações erradas. Contudo, esta distribuição equitativa dos valores não

9 AUC-Cabido, Livro de rendas da massa, III/D,1,1,3,103 (anos 1598-1654). 
deixa de ser artificial, já que estas igrejas não pagariam o mesmo valor, como por vezes a própria fonte menciona, embora não especificando os valores correspondentes a cada uma. Além do mais, este livro indica-nos se a igreja pagava a "terça" ou se era "toda do cabido", ou seja parte da renda ou a totalidade, informação essencial que nos ajuda a perceber a diferença, por vezes bastante significativa, dos valores pagos pelas diferentes igrejas. Nalguns casos é-nos ainda dito que o padroeiro daquela igreja é o Cabido.

De entre as 380 freguesias que compunham a diocese de Coimbra, 23\%, ou seja, 86 freguesias, pagavam esta renda ao Cabido. A estas acrescente-se ainda quatro lugares, além de outros cujas rendas pagas surgem juntamente com algumas daquelas 86 freguesias. A explicação para a distribuição geográfica das igrejas que pagavam as "terças" é desconhecida, mas certamente que remontará à idade média, momento histórico em que se terão definido quais as igrejas que pagavam o dízimo ao Cabido e, entre estas, as que o faziam na totalidade e as que apenas lhe entregavam uma terça parte, cabendo os outros dois terços ao bispo. Além disso, note-se que as igrejas de padroado do Cabido não coincidem com aquelas que pagavam as terças, logo não devendo haver qualquer relação entre estes dois aspectos, hipótese que chegamos a colocar quando decidimos cruzar ambas as variáveis no mapa 3.

$\mathrm{O}$ valor recebido pelo Cabido variava em cada arrendamento, certamente acompanhando a conjuntura económica ${ }^{10}$. Contudo, tal avaliação não nos interessa aqui, tendo optado por escolher um dos anos do séc. XVII - o de 1622 - representando cartograficamente, para cada igreja, os valores do arrendamento. Assim, através do mapa 3 é possível observar quais as igrejas que proporcionavam maiores ou menores rendas, hierarquia que se manteria ao longo do século.

A maior parte das freguesias que pagavam menor valor de renda situavam-se sobretudo no arcediagado de Seia, em particular no designado arciprestado de Linhares (com valores a rondar os 17500 cada uma) ${ }^{11}$. Contudo, no mesmo arcediagado encontrámos outras que pagavam valores significativos, em particular a de Tourais e suas anexas (Lajes, Paranhos e Girabolhos), mas também a de Avô e anexas (Anceriz, Aldeia da Dez, Pomares e Santa Olaia), o que se justifica por ambas pagarem a totalidade da renda ao Cabido. Entre as que pagavam valores

${ }^{10}$ Embora não tenhamos procedido a uma análise deste tipo, apresentamos em anexo um gráfico com os valores dos arrendamentos desta renda entre 1598 e 1654.

${ }^{11}$ A diocese estava dividida em arcediagados (Vouga, Penela, Seia e Cidade), tendo-nos surgido nesta fonte, pela primeira vez, a referência a um arciprestado, referência administrativa que desconhecíamos para a diocese. 
mais elevados encontravam-se as igrejas junto à foz do Mondego (Maiorca, Buarcos, couto de Tavarede e Lavos, com valores entre os 200 e os $250 \mathrm{mil}$ réis), bem como outras próximas de Coimbra, como Cantanhede (onde o Cabido tinha um celeiro), com 335 mil réis, ou Soure, com 302 mil réis, ou ainda, no arcediago de Vouga, o couto de Espinho, com 275 mil réis, Condeixa-a-Velha, com 335 mil réis, e Monçarros, com 262 mil réis. Em comum entre quase todas estas igrejas está o facto de pagarem a renda na íntegra e não a terça parte.

De registar também os espaços "vazios" evidenciados pelo mapa. Ainda que não de forma tão acentuada como a que vimos quando falámos das propriedades, é de notar a quase ausência de igrejas a pagar ao Cabido no extremo Norte da diocese, na maior parte do litoral e de quase todas as que se localizavam na

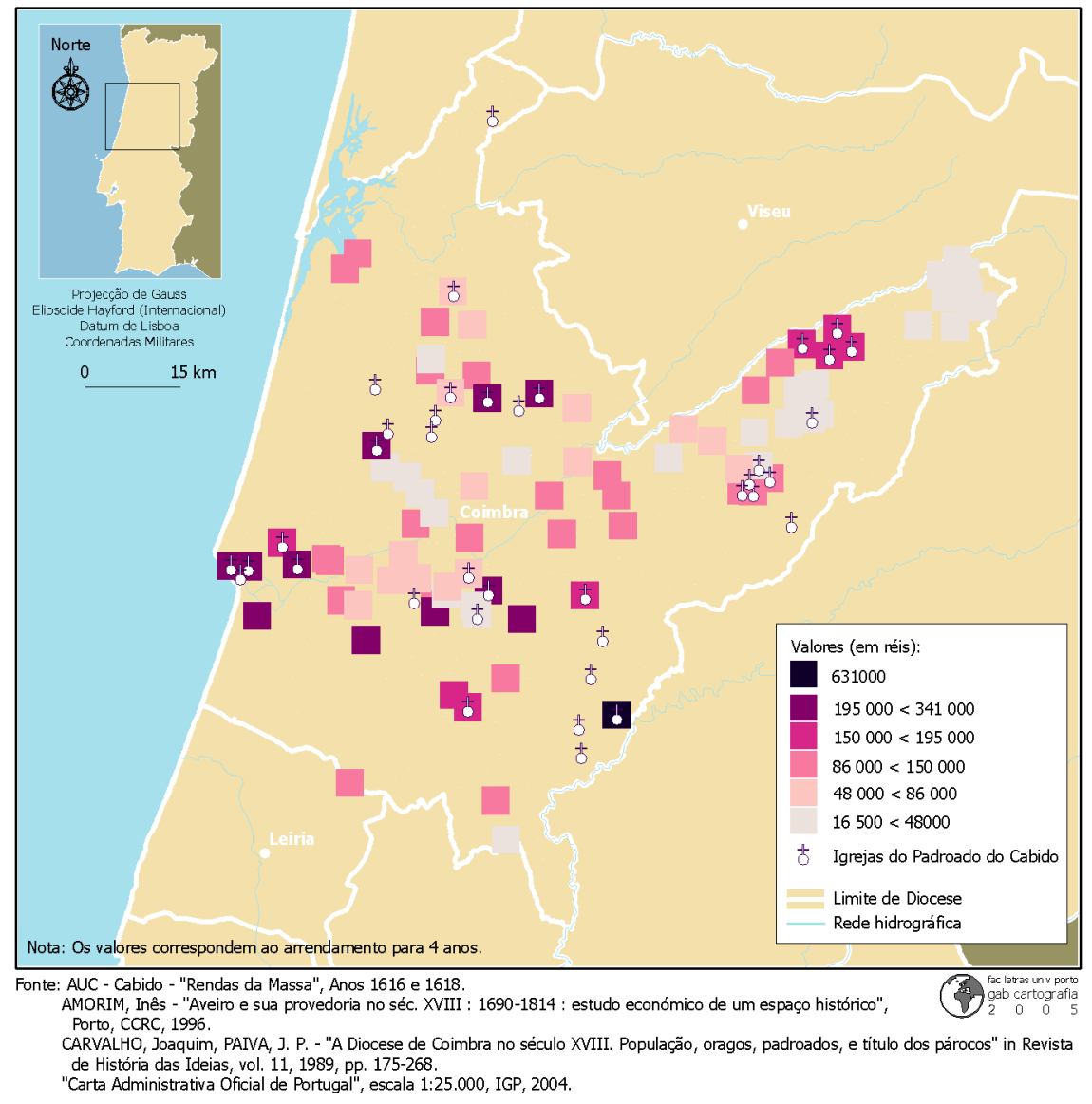

Mapa 3 - As “terças” do Cabido da Sé de Coimbra no arrendamento de 1622 
zona fronteiriça a Sul e Este da diocese. Curiosamente, é entre este quase vazio que se encontra aquela que, sozinha, pagava o valor mais elevado: Pedrógão Grande, "toda do Cabido", que rendia 631 mil réis, em 1622.

Com o arrendamento de 1622, o Cabido arrecadaria, anualmente, a elevada soma de 9.805.500 réis, além de outros géneros (cereal, lãs, castanhas, vinho...), que constituíam a chamada "ordinária", que a fonte indica, mas sem quantificar (com excepção da cera). Na verdade, nenhum dos livros que registaram esta renda nos dá tal informação, a qual só poderá ser obtida através dos contratos de arrendamento ${ }^{12}$.

Além destas igrejas, havia outras que pagavam as chamadas censorias, mas cujos valores, como se pode observar no quadro 2, eram bastante diminutos, não ultrapassando, no total, os 2.700 réis anuais.

Quadro 2 - Censorias pagas ao Cabido

\begin{tabular}{|l|c|}
\hline \multicolumn{1}{|c|}{ Igreja } & Valor (em réis) \\
\hline Lamas do Vouga & 300 \\
\hline Vale Maior & 100 \\
\hline Bemposta & 400 \\
\hline Macinhata do Vouga & 20 \\
\hline Cepelos & 360 \\
\hline Mosteiro de Lorvão & 300 \\
\hline Vagos & 100 \\
\hline Mosteiro de Celas & 20 \\
\hline Ega & 130 \\
\hline Soure & 400 \\
\hline Redinha & 130 \\
\hline Pombal & 400 \\
\hline Espinhal & 20 \\
\hline Paio Pardinho de Travanca & 20 \\
\hline & $\mathbf{2 7 0 0}$ \\
\hline
\end{tabular}

Fonte: AUC - Cabido, Lv. de foros (ano 1621)

\section{Distribuição das rendas}

Pelo que conseguimos observar, através das diversas fontes consultadas, e como já concluíra Fernando Taveira da Fonseca para a segunda metade do século XVIII, a quase totalidade dos rendimentos obtidos pelo Cabido era

${ }^{12}$ Os arrendamentos poderão ser encontrados nos livros de tabeliães da cidade, já que o Cabido não possuía, nesta altura, notário privativo. Para o séc. XVIII pode ser consultada, entre a documentação do cabido, o Livro dos negocios thoquantes à maça e rendas... III/D,1,1,3,105 (1742-1743), o qual parece tratar-se de um livro de notas, já que além de arrendamentos desta renda, regista empréstimos, contratos de missa, emprazamentos... 
distribuída pelos capitulares, ficando de fora, de acordo com aquele autor, apenas cerca de $10 \%$ do total, a fim de cobrir as despesas ${ }^{13}$. Ou seja, pagas diversas despesas, o remanescente era repartido pelos capitulares em porções individuais (a chamada prebenda).

$\mathrm{Na}$ época em estudo, o número de prebendas havia estabilizado em 32, mas uma delas era destinada à obra, ou seja, à fábrica da catedral. Além disso, desde 1586 que um cónego tinha de repartir metade dos rendimentos da sua conezia com a Inquisição ${ }^{14}$, conforme breve papal ${ }^{15}$. Importa agora conhecer como era feita a distribuição das rendas do Cabido pelos capitulares e qual o valor que cabia a cada um.

Para que os capitulares tivessem direito a receber, sem penalizações, as rendas do seu benefício, deveriam cumprir com o dever de assistir aos ofícios religiosos e às reuniões capitulares, cujo controlo era feito pelo contador do coro e registado em livros próprios ${ }^{16}$. Assim, ao remunerar-se apenas quem estivesse presente, pretendia-se, num contexto pós-tridentino, uma maior assiduidade dos capitulares e, por conseguinte, um melhor cumprimento das suas obrigações religiosas ${ }^{17}$.

Contudo, nem todos os capitulares alcançavam os mesmos níveis de rendimento. Desde logo, dividiam-se em dois grupos principais: os que tinham direito a uma prebenda inteira (dignidades e cónegos) e os que auferiam apenas de uma parte dessa prebenda: metade, no caso dos meios cónegos, ou um terço, no dos tercenários. Todavia, mesmo entre as dignidades existiam algumas diferenças na sua remuneração. $\mathrm{O}$ deão, além da prebenda, tinha direito às

${ }^{13}$ FONSECA, 1995: 128.

${ }_{14}$ AUC - Cabido, Acórdãos do Cabido, III/D,1,1,1,6, fol.152v (13-01-1586)

${ }^{15}$ Breve de Gregório XIII (28-07-1583). Vd. Collectorio das bullas e breves apostólicos..., 1634, fl. $137 \mathrm{v}-139$.

${ }^{16}$ AUC - Cabido, Livs. da Contadoria e Livs. das Festas dos Beneficiados da Sé.

${ }^{17}$ No entanto, por volta de 1628 , as disposições estatutárias não estariam a ser integralmente cumpridas sendo o assunto levado a Cabido, que relembrou que a naturesa das distribuiçois quotidianas e a causa de sua instituição não foi outra senão procurarse atrahir e convidar com ellas aos ministros de Deus para que com melhor vontade fossem assiduos e frequentes na veneração e culto divino, assistindo no coro, nas procissois, e mais officios divinos, e por essa razão, pellas horas canonicas, missas, e procissois fora dividido o merecimento das ditas distribuiçois destribuindosse por cada hora e mais officios o que pareseu bem, para que sós os que a elles assistissem com sua presença per seu trabalho recebessem o merecimento das ditas distribuiçois, que por essa causa o Concilio Tridentino manda que sós os que assistirem ás horas, e mais officios divinos recebão as distribuiçois e os mais sejão excluidos dellas (...). AUC - Cabido, Acórdãos do Cabido, III/D,1,1,1,11, fl. 115-116v (28-04-1628). 
"terças" (i.e., a parte dos dízimos) da Lousã ${ }^{18}$. O tesoureiro-mor e o mestreescola recebiam duas prebendas, tendo de, em contrapartida, fazer face a certas despesas, relacionadas com a manutenção e limpeza do templo, no caso do primeiro, ou com o pagamento a quem assegurasse o ensino na catedral, no caso do segundo. Contudo, desconhecemos qual o valor real destas despesas e, no fundo, qual o valor líquido que acabavam por auferir.

Já os arcediagos haviam perdido, há muito tempo, o direito a prebenda ${ }^{19}$. O do Vouga e o de Penela recebiam os dízimos de várias igrejas dos respectivos arcediagados sob o nome de eirádegos; e tanto estes dois como todas as dignidades capitulares, incluindo os arcediagos de Seia e da Cidade, recolhiam também algumas rendas especiais, que lhes eram consignadas na igreja de Soure ${ }^{20}$. Assim, se os réditos dos arcediagos de Vouga e Seia seriam relativamente significativos, os dos arcediagos da Cidade e de Seia eram quase nulos ${ }^{21}$. No entanto, conhecem-se poucas informações relativas ao valor destes rendimentos, já que a sua recolha estaria, muito provavelmente, a cargo dos próprios arcediagos ${ }^{22}$. Ao longo do período em estudo, quase todos os arcediagos encontraram, porém, uma forma de alcançar uma prebenda: acumulando a dignidade com um benefício na catedral, como cónegos ou até como porcionários ${ }^{23}$.

${ }^{18}$ Em 1667 levanta-se a dúvida sobre a quem pertenciam estas terças quando o deado estava vago, à qual o Cabido responde dizendo que a ditta terça da Louzã está imcorporada com a massa da nossa meza capitular e que quando vaga do Deado no tempo durante da vacatura se destribuem e repartem entre nos e os meios conegos e tercenarios desta see os fruitos do dito deado e os da terça da Louzã por andar imcorporada com a nossa massa (AUC - Cabido, Acórdãos do Cabido, III/D,1,1,1,13, fl. 239v (31-08-1667). Taveira da Fonseca afirma que o deão recebia, na segunda metade do século XVIII, 2/3 de uma prebenda, referindo, como fonte os livros de mesadas. Desconhecemos se ao longo do século XVIII houve alguma redução na prebenda do deão ou se seria apenas resultado de penalizações pelo não cumprimento integral das suas obrigações, como ocorria no séc. XVII. Vd. FONSECA, 1995: 133, nota 43. Segundo Carvalho da Costa, o deão tinha, além de uma prebenda inteira, direito a hum aprestimo com obrigação de correr com os negocios do Cabido. Vd. COSTA, 1868-1869: vol. 2, p. 5.

19 Vd. VASCONCELOS, 1940.

${ }^{20}$ VASCONCELOS, 1940: 14

${ }^{21}$ VASCONCELOS, 1940: 19-20. Utiliza como fonte: AUC - Cabido, Processo dos Arcediagos (III/D,1,3,1,148).

22 Bento de Almeida, em 1639, arrenda os frutos "eiradigos" do arcediagado de Penela, por 2 anos, a 105 mil réis por ano. Contudo, ele era arcediago do Vouga, e não de Penela, não tendo nós compreendido porque é que ele aparece aqui a negociar algo que não lhe diria respeito. AUC - Cartório Notarial de Coimbra, Tab. Simões Gomes Rebelo, V/I-Es/9/3/nº 98, fl. 74-76v (02-09-1639).

${ }^{23}$ Geralmente, os arcediagos acumulavam esta dignidade com uma conezia (inteira), mas, por vezes, teriam de se contentar com uma meia conezia, como Bento Ribeiro de Almeida, ou 
As rendas a que os capitulares tinham direito eram distribuídas em vários momentos do ano. De todas as rendas recebidas em dinheiro pelo Cabido, era retirado o que fosse necessário para despesas e gastos ordinários da instituição, sendo o restante repartido pelo número de prebendados existentes na altura. As mesadas representavam a fracção mais significativa e, como o próprio nome indica, consistiam em valores monetários que eram recebidos mensalmente. Duas vezes por ano, em Fevereiro e em Junho, era ainda distribuído o dinheiro de determinadas rendas, destinadas às chamadas $\mathrm{festas}^{24}$. Para que os capitulares recebessem a totalidade do valor correspondente àquele mês ou festas, teriam de ter cumprido a totalidade das suas obrigações e não ter sofrido qualquer penalização ("perdas"), cujo valor era sempre redistribuído posteriormente. No final de cada ano económico (em Junho) podiam ainda ser distribuídos os sobejos, caso, obviamente, restasse algum dinheiro. Era nesta ocasião que, juntamente com o valor das festas, se repartiam os chamados jaós ${ }^{25}$.

Além destes rendimentos, alguns capitulares eram remunerados por determinadas funções para que, anualmente, eram eleitos, como a de secretário ou contador do coro. Esses valores eram fixos e, ao longo do período em análise, não houve qualquer alteração.

Quadro 3 - Remuneração anual aos "oficiais"26

\begin{tabular}{|c|c|}
\hline Ofício & Valor (em réis) \\
\hline Contador do Coro & 6000 \\
\hline Contadores gerais (2) & 3000 (cada um) \\
\hline Secretário & 6000 \\
\hline Recebedor dos Terradegos & 2000 \\
\hline Celeireiro & 300 \\
\hline
\end{tabular}

Fonte: AUC - Cabido, Livs. de Mesadas.

Entre as obrigações dos beneficiados da Sé conta-se a participação numa série de procissões que se realizavam ao longo ano. Para além destas procissões ordinárias, os capitulares eram ainda compensados monetariamente por cada

\footnotetext{
uma tercenária, como João de Borba Fragoso (vd. este exemplo em CARVALHO: 2000).

${ }^{24}$ AUC - Cabido, Estatutos, cap. 80.

${ }^{25}$ Taveira da Fonseca diz tratar-se de uma pequena prestação diária, referindo ainda que se trata de um termo que não conseguiu identificar noutro local. FONSECA, 1995: 131.

${ }^{26}$ A fonte só indica o pagamento destes oficiais deixando de fora todos os outros (esmoler, apresentador da igrejas, visitadores dos coutos...). Fica a dúvida sobre a possibilidade de serem remuneradose da origem das receitas para o seu pagamento. O obreiro e o escrivão da obra, por exemplo, eram pagos através da obra, i.e., fábrica da Sé (Vd. AUC - Cabido, Lvs. da Obra).
} 
procissão extraordinária em que o Cabido participasse, quer fosse organizada por si, quer por outra instituição. Tal como nas festas, o pagamento era feito duas vezes por ano, em Fevereiro e em Junho, e só recebia o valor total quem tivesse estado presente em todas as procissões. Além deste conjunto de procissões, a partir de 1628 os capitulares passaram a poder auferir de uma doação feita pelo bispo D. João Manuel. Este prelado de Coimbra, quando morreu, deixou em doação mil cruzados, que deveriam ser rentabilizados para que, anualmente, os juros obtidos fossem distribuídos pelos capitulares presentes no oitavairo de Corpus Christi ${ }^{27}$.

Por último, refira-se os chamados "terradegos" 28 , juntamente com os quais se repartiam também as lutuosas, restituições e outras miudezas ${ }^{29}$. As lutuosas só seriam vencidas pelos beneficiados que estivessem na cidade, e/ou contados como presentes pelo Cabido (i.e., os ausentes da cidade em serviço do Cabido), quando chegasse a notícia que falecera a pessoa de que haveria lutuosa ${ }^{30}$. Não parece haver um intervalo de tempo fixo entre cada distribuição, ocorrendo em vários meses do ano ${ }^{31}$.

Através do gráfico 1, verificamos que o valor total, correspondente a uma prebenda inteira, não sofreu alterações significativas entre 1620 e $1670^{32}$. Todavia, parece haver dois momentos que constituem a excepção: em 1630 há uma quebra de cerca de 60 mil réis comparativamente ao ano de 1620 , e, em 1670, uma assinalável subida dos rendimentos, com mais 96 mil réis do que havia sido atingido dez anos antes. Mais do que os tempos de crise económica que marcaram os inícios da década de $1630^{33}$, aquela descida dever-se-á, sobretudo, ao facto de nesse ano não ter havido a remuneração das segundas festas (em Junho de 1631), bem como pelo facto das mesadas de cada prebendado ter sido retirada determinada quantia, tendo todo esse dinheiro

${ }^{27}$ AUC - Cabido, Liv. de Procissões e Pitanças, III/D, 1,4,1,6,fl. 10. Ao contrário de todas as outras ocasiões, aqui o mestre-escola e o tesoureiro-mor não viam o valor duplicar. Na doação insiste-se que só poderia ser remunerado quem estivesse presente na procissão, ficando de fora os doentes e os ausentes por qualquer outro motivo.

${ }^{28}$ Terá o mesmo significado que laudémio, ou seja, certa parte do preço ou avaliação do prédio vendido. Vd. COELHO, 1983: 305.

${ }^{29}$ AUC - Cabido, Livs. de Terradegos, III/D, 1,1,4, 39 a 73.

${ }^{30}$ AUC - Cabido, Estatutos, Cap. 82.

${ }^{31}$ AUC - Cabido, Livs. de Terradegos, III/D,1,1,4, 49 a 57 (1620 a 1670).

${ }^{32}$ Apresentamos aqui apenas os valores para o último ano de cada década (ou o mais próximo - vd. anexos), pois embora tenhamos começado por recolher dados para intervalos de tempo mais curtos, rapidamente nos apercebemos que os valores eram bastante estáveis.

${ }^{33}$ OLIVEIRA, 1976-1977: vol. 47, pp. 280-282. 


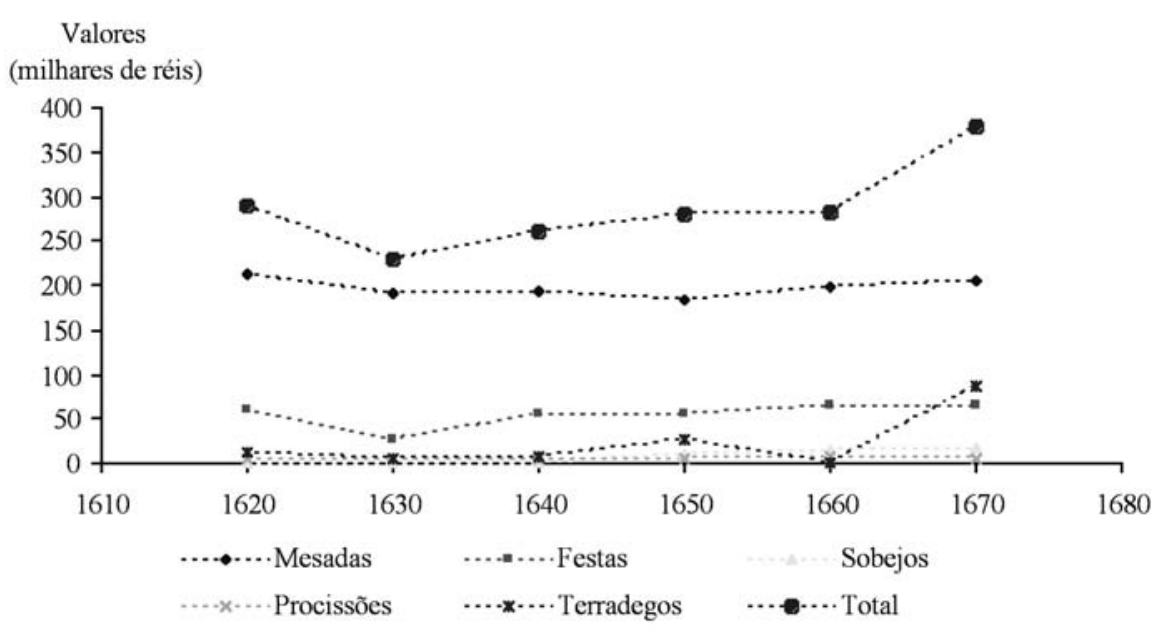

Fontes: AUC - Cabido, Livs. de Mesadas; Livs. de Procissões e Pitanças; Livs. Repartição dos Terradegos.

Gráfico 1 - Evolução dos valores repartidos por uma prebenda (1620-1670)

como destino o pagamento do subsídio pedido pelo Monarca ${ }^{34}$. A subida espectacular ocorrida em 1670 deve-se a um valor extraordinário recebido nesse ano e distribuído no livro dos terradegos: por breve papal de 14 de Junho de 1670 , Clemente $\mathrm{X}$ concedeu às dignidades e aos cónegos tudo o que tivessem recebido de selos, colações e lutuosas desde 24 de Julho de 1663 até à data do breve, pelo trabalho que tiveram por ser sede vacante. O Cabido decidiria alargar a repartição aos meios cónegos e tercenários, não por terem direito, mas por "graça e favor". Porém, estes não aceitaram, cabendo então 50 mil réis a cada dignidade e cónego ${ }^{35}$.

Se excluirmos estes dois casos excepcionais, parece ser notório que o rendimento de cada prebenda é relativamente estável ${ }^{36}$, embora nunca haja um montante rigorosamente fixo, o que terá a ver com a própria estabilidade das receitas que o Cabido recolhia, resultado do facto da chamada massa das rendas ser arrendada ${ }^{37}$. Todavia, importa relativizar os valores recebidos pelos capitulares, introduzindo na análise alguns dados sobre a conjuntura económica.

${ }^{34}$ Sobre este assunto, entre outros documentos, vd. AUC - Cabido, Liv. das festas, III/D, 1, 3, 5, 239 (1630-1640); Acórdãos do Cabido - III/D,1,1,1,11, fl. 26v (06-07-1626); ALMEIDA, 1973: 294. Vd. tb., por exemplo, SERRÃO, 1990: 103-104; PAIVA, 2000: 154-158.

${ }_{35}$ AUC - Cabido, Lv. de Terradegos, III/D, 1,1,4, 57 (1670).

${ }^{36}$ Ao contrário do que acontecia, por exemplo, em Huesca (Espanha), onde a renda recebida pelos cónegos variava em função da conjuntura económica. LATORRE CIRIA, 1992: 286.

${ }^{37}$ FONSECA, 1995: 125-127. 
Assim, seria aconselhável apresentar, ao lado do gráfico 1, um outro que representasse a evolução dos preços agrícolas. Contudo, não conseguimos reunir, para Coimbra, uma série contínua de preços que permita conclusões sólidas $^{38}$. Mesmo assim, é possível afirmar que, por exemplo, a referida quebra na repartição de rendimentos em 1630 terá afectado ainda mais o poder de compra dos capitulares se tivermos em consideração a alta de preços que marca grande parte da década. Do mesmo modo, os altos valores recebidos em 1670 deverão ser relativizados, já que os finais da década de 60 são, também eles, marcados por uma alta acentuada do preço do trigo ${ }^{39}$.

Quadro 4 - Rendimentos de alguns capitulares no ano de 1665/66 (em réis)

\begin{tabular}{|c|c|c|c|c|c|c|c|}
\hline & $\begin{array}{c}\text { Valor } \\
\text { máximo } \\
\text { auferível por } \\
\text { prebenda }\end{array}$ & $\begin{array}{c}\text { Clemente } \\
\text { de } \\
\text { Magalhães } \\
\text { Deão }\end{array}$ & $\begin{array}{c}\text { Matias } \\
\text { Pinheiro } \\
\text { Arc. Seia e } \\
\text { Cónego }\end{array}$ & $\begin{array}{l}\text { Duarte de } \\
\text { Melo }\end{array}$ & $\begin{array}{c}\text { Manuel } \\
\text { Pimentel } \\
\text { Cónego }\end{array}$ & $\begin{array}{c}\text { José } \\
\text { Auphante } \\
\text { Meio Cónego }\end{array}$ & $\begin{array}{c}\text { Manuel } \\
\text { Gomes } \\
\text { Tercenário }\end{array}$ \\
\hline Mesadas & 191260 & 188560 & 181310 & 381540 & 191060 & 95630 & 63530 \\
\hline Festas & 61680 & 60160 & 56500 & 123300 & 61680 & 30840 & 20550 \\
\hline Procissões* & 5660 & 4210 & 3490 & 10080 & 2400 & 0 & 0 \\
\hline Sobejos ${ }^{* *}$ & 0 & 0 & 0 & 0 & 0 & 0 & 0 \\
\hline Terradegos & n.i. & 20580 & 19020 & 39490 & 20580 & 11290 & 6839 \\
\hline Igreja de Soure $^{* * * *}$ & - & ? & ? & $?$ & - & - & - \\
\hline Terças da Lousã & - & $?$ & - & - & - & - & - \\
\hline Total & - & $>273510$ & c. 260320 & c. 554410 & 275520 & 137560 & 90719 \\
\hline
\end{tabular}

Fontes: AUC - Cabido, Lv. de Mesadas; Lv. Procissões e Pitanças; Lv. Terradegos.

* Neste ano não aparecem os porcionários, o que estará relacionado com os conflitos internos entre estes e os dignidades e cónegos.

** Não houve distribuição de sobejos neste ano.

**** VASCONCELOS, 1940: 19-20. Utiliza como fonte: AUC - Processo dos Arcediagos. Em finais do século XVIII renderiam 200 réis. Utilizando como fonte um livro de rendas da massa, onde se registavam as "terças" de Soure, não conseguimos obter um valor aproximado daquele, mas sim significativamente superior. Assim, optámos por não incluir qualquer valor na tabela. Vd. AUC - Cabido, Liv. Rendas da Massa, III/D,1,1,3,103 (1616-1654).

${ }^{38}$ Os dados que conseguimos obter são apresentados em anexo, inclusivamente sob a forma de gráfico. Utilizámos como fontes, documentação do próprio Cabido: todos os livros da obra que conseguimos identificar no AUC, e alguns livros do celeiro. Estas são, aliás, algumas das fontes utilizadas, para a análise dos preços, por António de Oliveira em A Vida Económica e Social de Coimbra de 1537 a 1640. (Vd. OLIVEIRA, 1976-1977: vol. 48, pp. 181-192).

${ }^{39}$ Note-se ainda que, entre os referidos livros da obra, há anos em que esta vende cereal e outros em que tem necessidade de o comprar, o que poderá ser mais um indicador da falta de cereal. 
Se o gráfico 1 apresenta os valores máximos que cada cónego ou dignidade poderia receber se não sofresse qualquer penalização e se cumprisse com todas as suas obrigações, não nos esqueçamos, ainda, que os porcionários só recebiam parte daquele rendimento (metade ou uma terça parte), e o tesoureiro e o mestre-escola viam aquele valor duplicar. Ou seja, só uma análise minuciosa de toda esta contabilidade nos permitiria saber quais os valores reais que cada capitular auferia, e mesmo assim seria difícil identificar o valor de certas rendas recebidas por alguns deles, como é o caso do deão ou dos arcediagos do Vouga e Penela. A título meramente exemplificativo, seleccionámos alguns capitulares e procurámos saber qual o valor efectivo dos rendimentos, em dinheiro, que conseguiram obter no ano económico de 1665/66, e que apresentamos no quadro 4. Facilmente se pode constatar que todos acabavam por sofrer um qualquer tipo de penalização, por mínima que fosse. Por exemplo, no caso das procissões, as penalizações, certamente por falta de comparência, parecem ter sido relativamente significativas, se atendermos ao valor diferencial entre o máximo correspondente a uma prebenda inteira e o realmente recebido. Todavia, se tivermos em atenção os elevados valores envolvidos, concluiremos que o saldo final não era muito afectado.

Quadro 5 - Géneros repartidos por cada prebenda no ano de 1665/66

\begin{tabular}{|cc|c|}
\hline \multicolumn{2}{|c|}{ Género } & Quantidade/Unidades \\
\hline \multirow{3}{*}{ Cera } & 34 arráteis \\
\cline { 2 - 3 } Aves & capão & 28 \\
\cline { 2 - 4 } & frangão & 8 \\
\cline { 2 - 4 } & ovos & 212 \\
\hline \multirow{3}{*}{ Cereais } & galinhas & 54 \\
\cline { 2 - 4 } & trigo & 75,5 alqueires \\
\cline { 2 - 4 } & cevada & 79,25 alqueires \\
\hline \multicolumn{2}{c|}{ milho } & 249,25 alqueires \\
\hline \multicolumn{2}{c|}{ Azeite } & 55 alqueires \\
\hline Sal, linho, legumes... & 20 almudes \\
\hline
\end{tabular}

Fontes: AUC - Cabido, Lv. de Mesadas; Lv. Capões; Lv. do Celeiro; Lv. do Azeite.

" Foi escolhido como exemplo o caso do cónego Manuel Pimentel, já que as quantidades/tipo de género variavam de capitular para capitular, o que estava relacionado com o tipo de foro pago por cada propriedade.

Além dos rendimentos pagos em dinheiro, cada prebendado recebia uma série de géneros, sobretudo alimentares. Anualmente era distribuída determinada quantidade de cera, que ficava registada nos livros de mesadas. O controlo da 
distribuição dos restantes géneros ficava assente nos livros respectivos: capões (aves), celeiro e azeite.

No caso das aves ${ }^{40}$, listavam-se apenas as propriedades, rústicas ou urbanas, cujo senhorio era o Cabido, que pagavam parte da renda com aquele género. A cada conjunto de propriedades era atribuído um número e, depois, fazia-se um sorteio, que teria uma validade de cerca de dez anos, em que cada beneficiado ficava a saber quem eram os inquilinos do Cabido que lhe teriam de pagar as aves. Na distribuição do azeite seguia-se um procedimento semelhante, mas para cada propriedade (eram cerca de $150^{41}$ ) indicava-se o nome dos capitulares a quem os inquilinos tinham de entregar o azeite. Visto que o número de propriedades que o Cabido possuía terá permanecido estável ao longo do século XVII, os valores recebidos também não terão sofrido grandes alterações. Assim, a cada prebenda inteira cabia, anualmente, cerca de 55 alqueires de azeite. No caso das aves é mais difícil fazer-se a contabilização, já que os foros eram pagos em vários tipos de aves, que diferiam de propriedade para propriedade.

Quanto aos cereais, a sua distribuição estava bem regulamentada nos estatutos $^{42}$, podendo a prática ser observada através dos livros do celeiro ${ }^{43}$. Primeiro retirava-se o cereal necessário para pagar determinados custos (medidor, carreteiro...) e parte dos salários de funcionários do Cabido; mas a maior parte do cereal era distribuída pelos capitulares em três porções: o pão da prebenda, que aparentemente cada capitular ia retirando do celeiro à medida das suas necessidades; o pão dos aniversários, repartido pelas 52 segundas-feiras do ano; e o pão das festas. As contas eram sempre concebidas de modo a que a distribuição do cereal fosse feita por 32 prebendas, mas caso durante o ano o seu número fosse menor, ou seja, caso alguma prebenda estivesse vaga, o cereal que lhe corresponderia seria redistribuído em Julho, Agosto e Setembro. Se, mesmo assim, depois de toda esta distribuição, restasse algum cereal no celeiro (o chamado "resíduo"), este era repartido no dia de Espírito Santo.

A forma como cada capitular geria o seu cereal não se mostra clara ao observarem-se os livros do celeiro. Por esclarecer fica, sobretudo, se o cereal, a que cada capitular tinha direito, era todo para consumo próprio ou se o colocavam no mercado. Alguns arrendariam os frutos de sua prebenda (todos os frutos do celeiro em pão, vinho, azeite, legumes, aves, linho, cebolas...), como fez o meio cónego Paulo Lopes da Paz, que os arrendou por quatro anos,

\footnotetext{
${ }^{40}$ AUC - Cabido, Livs. Capões, III/D, 1, 1, 4, 1 a 29 (1540-1842).

${ }^{41}$ AUC - Cabido, Receita das pensões em azeite, III/D, 1, 1, 4, 129 a 140 (1508-1822).

${ }^{42}$ AUC - Cabido, Estatutos, cap. 81.

${ }^{43}$ AUC - Cabido, Livs. do Celeiro, III/D,1,2,1,1 a 47 (1620-1670).
} 
num valor total de 160 mil réis ${ }^{44}$. Tal constitui mais uma prova da estabilidade de rendimentos que atrairia rendeiros.

Nestes livros do celeiro, além dos cereais, deveriam ficar registadas as distribuições de outros géneros, tais como cebolas, legumes, feijão, sal, linho e vinho. Contudo, em todos os livros que consultámos, embora estivessem assinaladas as páginas destinadas a esse efeito, geralmente não era deixado qualquer registo indicando as quantidades distribuídas por cada capitular. Por vezes, surge a listagem com os apelidos dos capitulares, seguida de "pg" (pago), certamente indicando que lhe haviam sido entregues os géneros em questão. No caso do vinho, conseguimos obter algumas quantidades que couberam a cada prebenda através de registos nos livros de acórdãos ${ }^{45}$.

\section{Conclusão}

Com o presente texto julgamos ter dado um contributo para o conhecimento do património do Cabido da Sé de Coimbra no século XVII. Por um lado, foi possível identificar o seu património fundiário e imobiliário e, por outro, as mais importantes rendas que recebia, de que se destacam as "terças". Ficamos a saber que o Cabido não explorava directamente as suas propriedades, emprazando-as. A ele cabia a administração de todos os bens, que, porém, beneficiavam cada capitular em particular. Uma gestão colectiva para um usufruto individual. Por vezes, no caso dos foros pagos em géneros, a recepção dos mesmos era feita directamente por cada capitular, como por exemplo no caso do azeite, mas, na maior parte dos casos, cabia ao Cabido a redistribuição das rendas por cada um dos seus membros.

Contudo, muitas questões ficam em aberto. O retrato que aqui apresentamos é estático, sendo necessário, em estudos futuros, perceber de que forma o Cabido geria o seu património e que evoluções se podem detectar na longa duração, bem como observar qual o impacto de crises económicas nos rendimentos da instituição.

${ }^{44}$ AUC - Cartório Notarial de Coimbra, Tab. Manuel Bernardes da Cruz, V/I-Es/9/5/nº 88, fl. 111 (14-12-1633).

${ }^{45}$ A distribuição do vinho não se encontra registada nos livros do celeiro, embora estes reservem espaço para tal, mas sim nos livros de acórdãos, ainda que, aparentemente, não de forma regular. $\mathrm{O}$ valor de 20 almudes, apresentado no quadro, corresponde ao ano de 1645 (AUC - Cabido, Acórdãos do Cabido, III/D,1,1,1,13, fl. 56), havendo registos para anos anteriores, que variam entre os 18 e os 27 almudes. 


\section{Anexos}

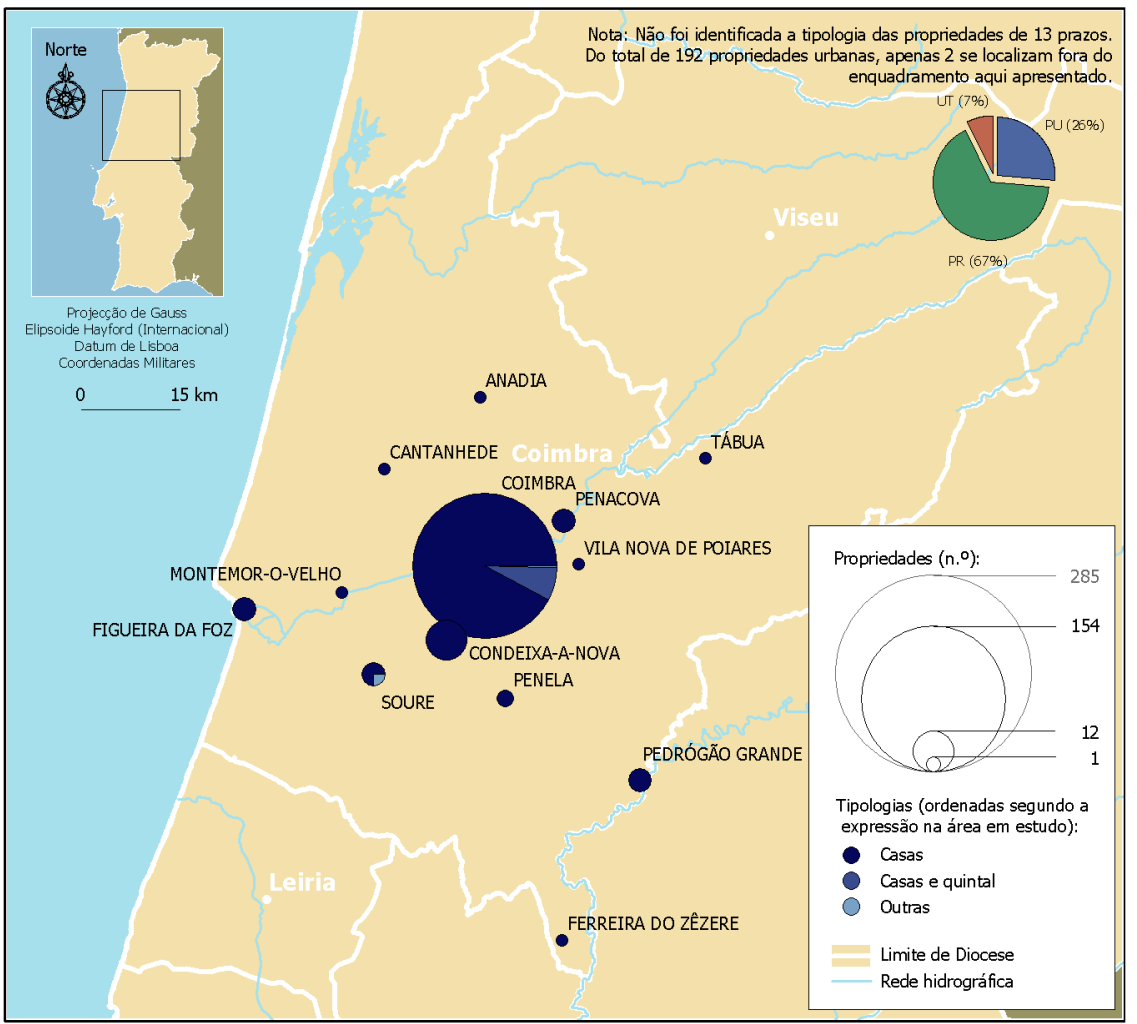

Fonte: AUC - Cabido - "Index das casas e propriedades do Cabido", Ano 1634; "Livro de Foros", Ano 1621

AMORIM, Inês - "Aveiro e sua provedoria no séc, XVIII : 1690-1814 : estudo económico de um espaço histórico",

Porto, CCRC, 1996.

CARVALHO, Joaquim, PAIVA, J. P. - "A Diocese de Coimbra no século XVIII. População, oragos, padroados, e título dos párocos" in Revista de Histónia das Ideias, vol. 11, 1989, pp. 175-268.

"Carta Administrativa Oficial de Portugal", escala 1:25.000, IGP, 2004.

Mapa 4 - Propriedades urbanas do Cabido da Sé de Coimbra no século XVII 


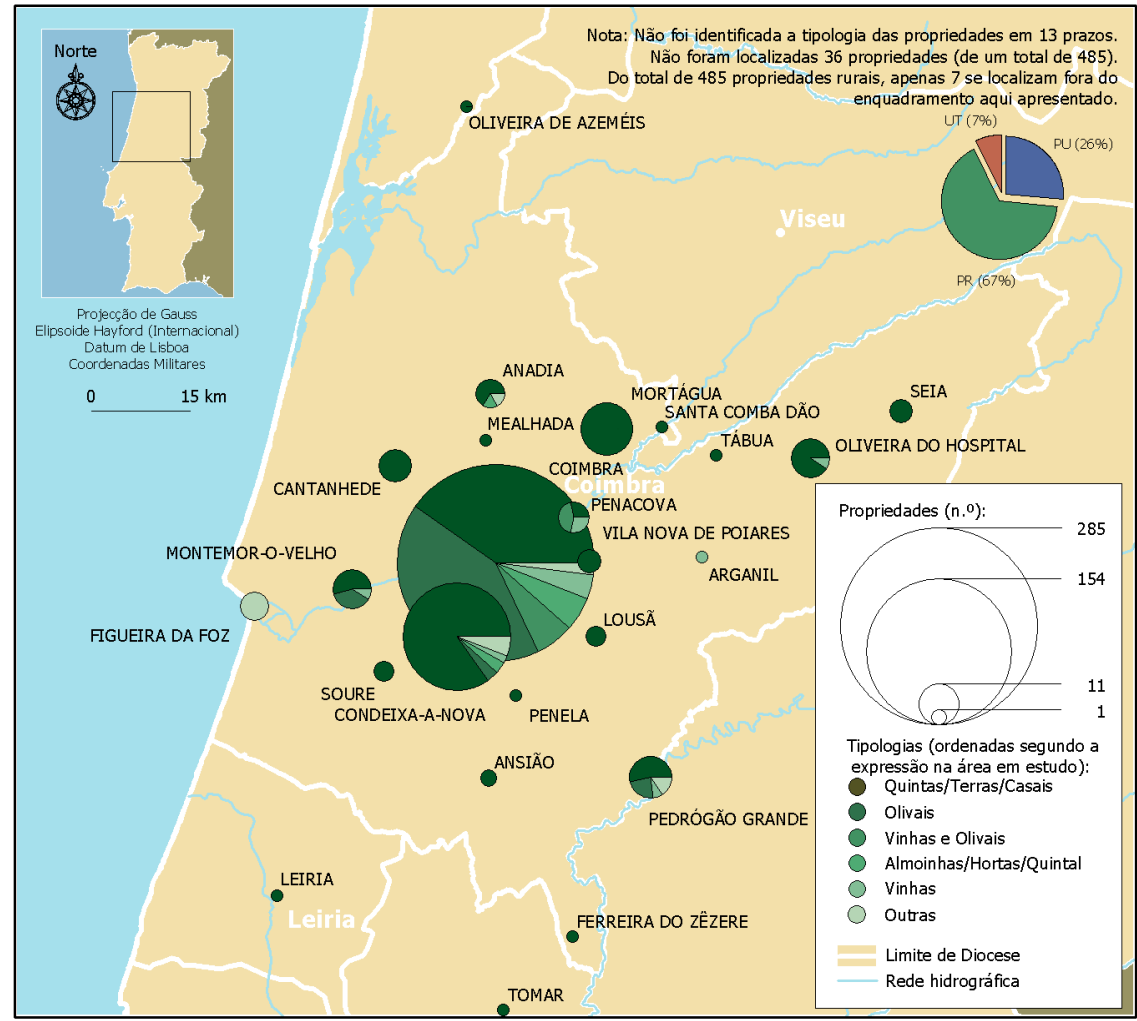

Fonte: AUC - Cabido - "Index das casas e propriedades do Cabido", Ano 1634; "Livro de Foros", Ano 1621.

AMORIM, Inês - "Aveiro e sua provedoria no séc. XVIII : 1690-1814 : estudo económico de um espaço histórico",

Porto, CCRC, 1996.

CARVALHO, Joaquim, PAIVA, J. P. - "A Diocese de Coimbra no século XVIII. Populaçăo, oragos, padroados, e título dos párocos" in Revista de História das Ideias, vol. 11, 1989, pp. 175-268.

"Carta Administrativa Oficial de Portugal", escala 1:25.000, IGP, 2004.

Mapa 5 - Propriedades rurais do Cabido da Sé de Coimbra no século XVII 


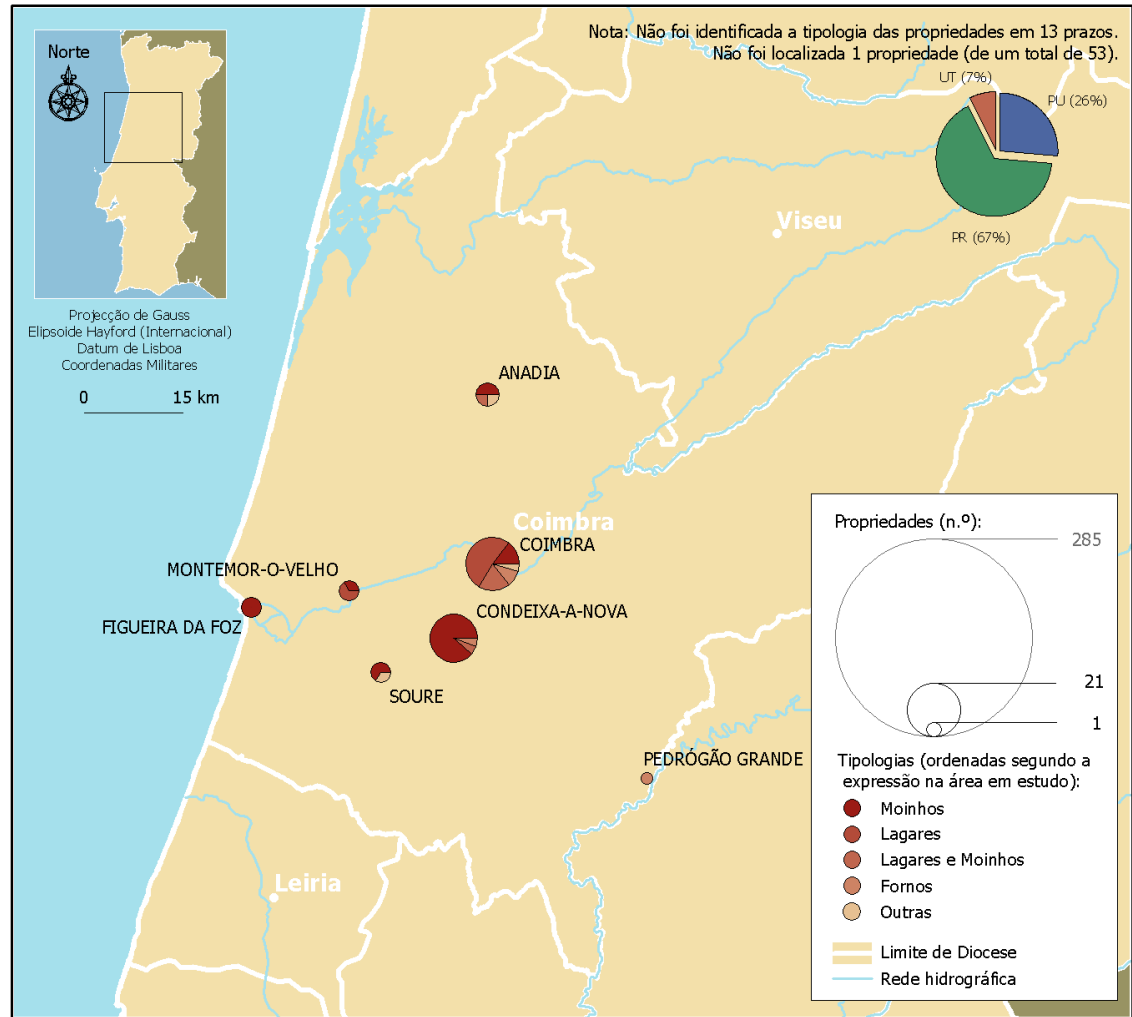

Fonte: AUC - Cabido - "Index das casas e propriedades do Cabido", Ano 1634; "Livro de Foros", Ano 1621.

AMORIM, Inês - "Aveiro e sua provedoria no séc. XVIII : 1690-1814 : estudo económico de um espaço histórico",

Porto, CCRC, 1996

CARVALHO, Joaquim, PAIVA, J. P. - "A Diocese de Coimbra no século XVIII. População, oragos, padroados, e título dos párocos" in Revista

de História das Ideias, vol. 11, 1989, pp. 175-268.

"Carta Administrativa Oficial de Portugal", escala 1:25.000, IGP, 2004

Mapa 6 - Unidades de transformação do Cabido da Sé de Coimbra no século XVII 


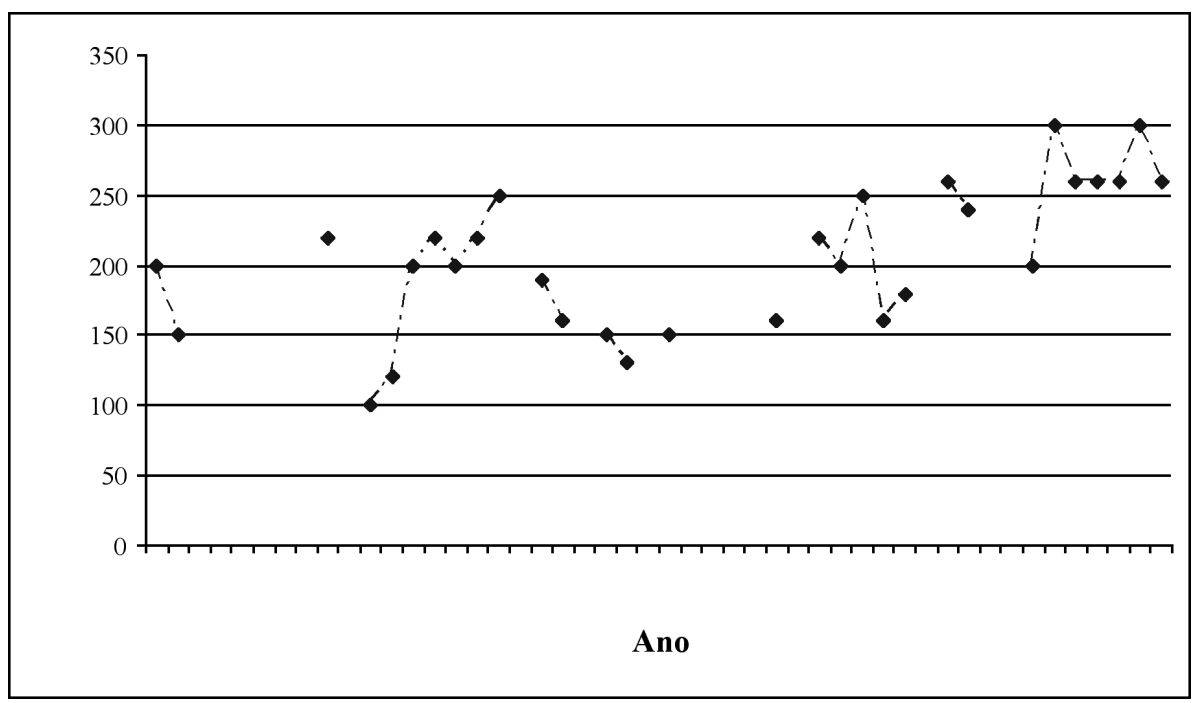

Fontes: AUC - Cabido, Livs. do Celeiro e Livs. da Obra; OLIVEIRA, 1976-1977.

Gráfico 2 - Evolução do preço do trigo em Coimbra (1620-1667) 
Quadro 6 - Preço, em réis, do cereal em Coimbra (1620-1667)

\begin{tabular}{|c|c|c|c|c|}
\hline Ano & Trigo & Cevada & Centeio & Milho \\
\hline 1620 & 200 & & & \\
\hline 1621 & 150 & 80 & 80 & 80 \\
\hline 1628 & 220 & & & \\
\hline 1630 & 100 & & & \\
\hline 1631 & 120 & & & \\
\hline 1632 & 200 & & & \\
\hline 1633 & 220 & 120 & 100 & \\
\hline 1634 & 200 & 100 & 100 & \\
\hline 1635 & 220 & 120 & 140 & 80 \\
\hline 1636 & 250 & & & 100 \\
\hline 1638 & 190 & & & \\
\hline 1639 & 160 & & & \\
\hline 1641 & 150 & & & \\
\hline 1642 & 130 & & & \\
\hline 1643 & & 100 & 100 & 100 \\
\hline 1644 & 150 & 100 & 100 & 70 \\
\hline 1649 & 160 & 100 & 100 & 120 \\
\hline 1651 & 220 & 130 & 100 & 120 \\
\hline 1652 & 200 & 120 & 100 & 100 \\
\hline 1653 & 250 & 160 & 100 & 120 \\
\hline 1654 & 160 & 100 & 80 & 100 \\
\hline 1655 & 180 & 80 & 80 & 80 \\
\hline 1657 & 260 & 150 & 100 & 110 \\
\hline 1658 & 240 & 130 & 100 & \\
\hline 1659 & & 120 & 120 & 110 \\
\hline 1660 & & 120 & 100 & 100 \\
\hline 1661 & 200 & 120 & 100 & 130 \\
\hline 1662 & 300 & 160 & 130 & 120 \\
\hline 1663 & 260 & 120 & 100 & 100 \\
\hline 1664 & 260 & 120 & 80 & 100 \\
\hline 1665 & 260 & 120 & 140 & 100 \\
\hline 1666 & 300 & & & \\
\hline 1667 & 260 & & & \\
\hline
\end{tabular}

Fontes: AUC - Cabido, Livs. do Celeiro e Livs. da Obra; OLIVEIRA, 1976-1977. 
Quadro 7 - Valor, em réis, de alguns géneros na cidade de Coimbra (1620-1653)

\begin{tabular}{|c|c|c|c|c|c|}
\hline Ano & Ovo & Frangão & Galinha & $\begin{array}{c}\text { Vinho } \\
\text { (quartilho) }\end{array}$ & $\begin{array}{c}\text { Azeite } \\
\text { (quartilho) }\end{array}$ \\
\hline 1620 & 3 & 24 & 80 & 7 & 20 \\
\hline 1625 & 3 & 20 & 80 & 13 & 20 \\
\hline 1630 & 3 & & 80 & 4 & \\
\hline 1635 & 3 & 25 & 100 & 4 & 22 \\
\hline 1653 & 3 & 25 & 108 & 8 & 24 \\
\hline
\end{tabular}

Fonte: AUC - Colégio de S. Pedro, Despesas da Superintendência da Cozinha, III/D, 1,7,5, 24-26,28 (Esta fonte foi-nos sugerida por PAIVA, 2004: 183).

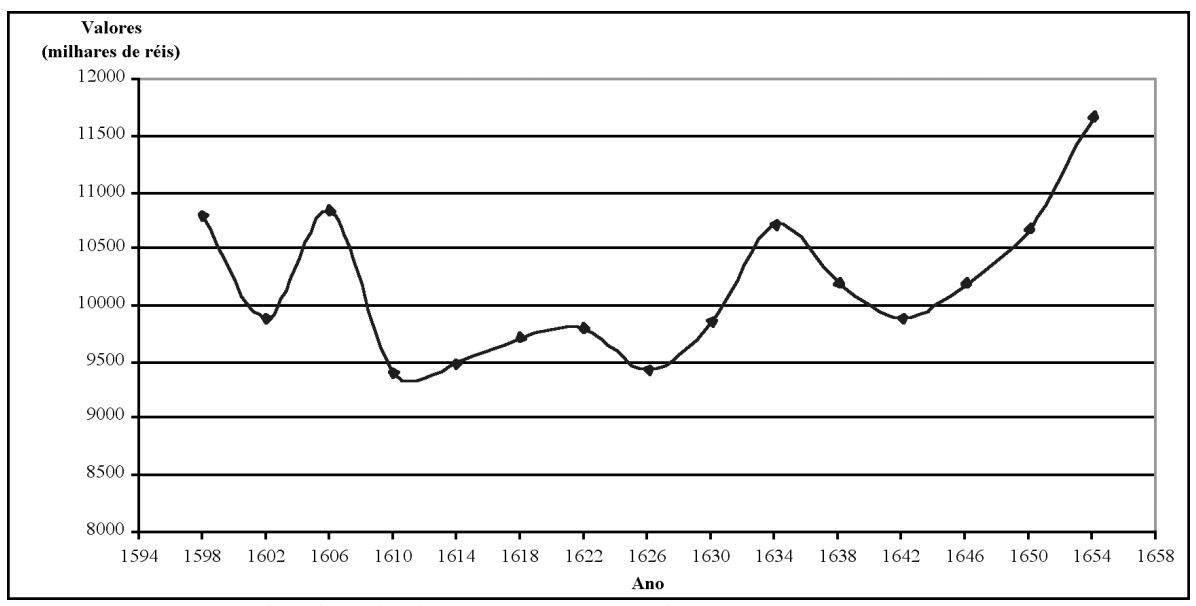

Fonte: AUC - Cabido, Livro de rendas da massa (1598-1654), III/D,1,1,3,103.

Gráfico 3 - As “terças” do Cabido de Coimbra (1598-1654) 


\section{Fontes}

\section{Arquivo da Universidade de Coimbra (AUC)}

\section{Fundo do Cabido}

Acórdãos do Cabido - III/D,1,1,1,6

$$
\begin{aligned}
& \text { III/D, } 1,1,1,11 \\
& \text { III/D, } 1,1,1,13
\end{aligned}
$$

Capões, Lvs. - III/D, 1, 1, 4, 1 a 29 (1540-1842)

Celeiro, Lvs. - III/D, 1,2,1,1 a 47 (1620-1670)

Contadoria do coro da Sé, Lvs. - III/D,1,1,2,1 a 41 (1633-1673)

Estatutos do Cabido, 1571 (cópia do século XVIII)

Festas beneficiados da Sé de Coimbra, Lvs. - III/D,1,3,5,239-242 (1630-1672)

Foros, Lvs. - III/D, 1,3,5,248 (1621)

$$
\begin{aligned}
& \text { III/D, 1,3,1,175 (1660-1663) } \\
& \text { III/D, 1,4,1,26 (1708-1722) }
\end{aligned}
$$

Index das casas e propriedades do Cabido - III/D, 1,3,4,14 [1634]

Livro dos negocios thoquantes à maça e rendas... - III/D, 1,1,3,105 (1742-1743)

Mesadas dos cónegos, meios cónegos e tercenários da Sé - III/D,1,3,1, 53 a 99 (1620-1668)

Obra da Sé, Lvs. de receita e despesa da - III/D,1,1,4, 110-116 (1617-1666)

Procissões e pitanças, Lvs. - III/D, 1,5,3,45 (1620-1632)

$$
\text { III/D, 1,4,1,6 (1632-1648) e } 7 \text { (1663-1677) }
$$

Receita das pensões em azeite - III/D, 1, 1, 4, 129 a 140 (1508-1822)

Rendas da massa, Lv. - III/D,1,1,3,103 (1598-1654)

$$
\text { III/D, } 1,1,3,102 \text { (1618) }
$$

Terradegos, Lvs. - III/D,1,1,4, 49 a 57 (1620 a 1670)

\section{Fundo Notarial}

Tab. Manuel Bernardes da Cruz, V/I-Es/9/5/nº 88

Tab. Simões Gomes Rebelo, V/I-Es/9/3/nº 98

\section{Colégio de S. Pedro}

Despesas da Superintendência da Cozinha, III/D,1,7,5, 24-26,28 (1620-1658) 


\section{Impressas ou Publicadas}

ALMEIDA, Manuel Lopes de, 1973 - Acordos do Cabido de Coimbra (1580-1640). Separata de "Arquivo Coimbrão", vol. 25 e 26.

Collectorio das bullas e breves apostolicos, cartas alvarás e provisoe[n]s reaes que contem a instituição \& progresso do Sancto Officio em Portugal..., Lisboa nos Estaos, por Lourenço Craesbeeck, 1634.

COSTA, António Carvalho da, 1868-1869 - Corografia portugueza, e descriçam topografica do famoso reyno de Portugal..., $2^{\mathrm{a}}$ ed., Braga, Typographia de Domingos Gonçalves Gouveia, vol. 2.

\section{Bibliografia}

CANÓVAS BOTÍA, Antonio, 1994 - Auge y decadencia de una instituición eclesial: El cabildo catedral de Murcia en el siglo XVIII. Iglesia y sociedad, Murcia, Universidad de Murcia.

CARVALHO, João Manuel Saraiva de, 2000 - Os cónegos da Sé de Coimbra. Subsídios para a história eclesiástica da diocese Conimbricense. I-Operiodo filipino (1580-1640), "Boletim do Arquivo da Universidade de Coimbra", Coimbra, Arquivo da Universidade, 19/20, pp. 115-166.

COELHO, Maria Helena da Cruz, 1983 - O Baixo Mondego nos finais da Idade Média - Estudo de História Rural, Coimbra, Faculdade de Letras.

FONSECA, Fernando Taveira da, 1995 - As contas do cabido da sé de Coimbra (1760-1775) - Nota de Investigação, "Revista Portuguesa de História", Coimbra, Faculdade de Letras da Universidade de Coimbra, vol. 30.

IRIGOYEN LÓPEZ, Antonio, 2001 - Entre el Cielo y la Tierra, entre la familia y la institución. El Cabildo de la Catedral de Murcia en el siglo XVII, Murcia, Universidad de Murcia, Servicio de Publicaciones.

LATORRE CIRIA, José Manuel, 1992 - Economía e religión. Las rentas de la Catedral de Huesca y su distribuición social (siglos XVI-XVII), Zaragoza-Huesca, Instituto Fernando el Católico-Instituto de Estudios Altoaragoneses.

OLIVEIRA, António de, 1976-1977 - A Vida Económica e Social de Coimbra de 1537 a 1640, "Biblos - Revista da Faculdade de Letras", Coimbra, Universidade de Coimbra, vols. 47 e 48 (anos de 1971-1972).

OLIVEIRA, Aurélio de, 1999 - O Clero em Portugal. Património e Bens da Época Moderna. In LANDI, Fiorenzo, ed. - Accumulation ad dissolution of large estates of the regular clergy in early modern Europe, Rimini, Guaraldi, pp. 199-232. 
PAIVA, José Pedro, 2000 - A Igreja e o Poder. In AZEVEDO, Carlos MOREIRA, dir. - História Religiosa de Portugal, Rio de Mouro, Círculo de Leitores, vol. 2, pp. 135-185.

PAIVA, José Pedro, 2004 - O episcopado e a "assistência" em Portugal na Época Moderna (séculos XVI-XVII). In Igreja, Caridade e Assistência na Península Ibérica (sécs. XVI-XVII). Lisboa, Edições Colibri-CIDEHUS-UE, pp. 167-196.

VASCONCELOS, António, 1940 - Dignidades do Cabido de Coimbra: o arcediagado do Vouga, "Arquivo do Distrito de Aveiro", Aveiro, vol. 6, no 21, pp. 5-35. [Publicado em CD-ROM: UNIVERSIDADE DE AVEIRO, 2000 - Arquivo do Distrito de Aveiro, Aveiro, Universidade de Aveiro, Fundação João Jacinto de Magalhães, $\left.C D n^{\circ} 1.\right]$

SERRÃO, Joaquim Veríssimo, 1990 - História de Portugal, 2 ${ }^{\mathrm{a}}$ ed., Mem Martins, Verbo, vol. 4 (Governo dos Reis Espanhóis - 1580-1640).

SOARES, Sérgio Cunha, 1995 - O município de Coimbra: da Restauração ao Pombalismo - poder e poderosos da Idade Moderna, Coimbra, Faculdade de Letras. [Dissertação de Doutoramento apresentada à Faculdade de Letras da Universidade de Coimbra]

STUMPO, Enrico, 1986 - Il consolidamento della grande proprietà ecclesiastica nell'età della Controriforma. In Storia d'Italia - La Chiesa e il potere politico. Torino: Giulio Einaudi editores, vol. 9, pp. 265-289. 